\title{
Strengths and Weaknesses of Education 4.0 in the Higher Education Institution
}

\author{
Rasika Lawrence, Lim Fung Ching, Haslinda Abdullah
}

\begin{abstract}
The Malaysian Higher Education has implemented an education 4.0 program in line with the 4th industrial revolution. The education 4.0 program is aimed at providing graduates with the capabilities and competencies required by the digital-driven industry. The purpose of this paper is to discuss the strengths and weaknesses of education 4.0 in Malaysia education industry. Lectures in a selected organisation are chosen for data collection purposes. Data was collected through interviews and. Data obtained through interviews and focus group discussions session is analysed using content and analytic induction analysis. Data are sorted and categorised into themes to theorized the strengths and weaknesses of Education 4.0 in Malaysia. The findings of this study found that education 4.0 creates an opportunity for educators to engage in new technology tools and it enhances the knowledge of the educators on technology more in depth. It also helps lecturers and students to enhance their knowledge \& usage of technology in depth. In addition, it promotes the development of technology classroom into the 21st century skills. However, there is high resistance to change in adapting and shift the mind set of lecturers towards adopting technology-based education as it can limit the engagement or involvement of an educator with the students. Technology is also found to be disconnecting learners from the real world. This study provides insights of the strengths and weaknesses of education 4.0 to the Ministry of Higher Education Malaysia and to the academics so that strategies in maximising the strengths and strategies in overcoming the weaknesses of education 4.0 can be developed.
\end{abstract}

\section{Keywords: Education 4.0, Technology-based, Malaysia}

\section{INTRODUCTION}

The education industry has enormously changed ever since the first industrial revolution took place. With the great findings of Artificial Intelligence (AI), robotics, big data and the internet, the impacts on jobs and industry have increased. During the 1780s, education was not given much importance to no expectations. People learnt on trading and survived. Whereas, during the second revolution, skilled workers were needed in the workforce. The existence of education played an important role during this period. Students attended school with no prior knowledge and subject was being taught. During this transition of time, teachers played a significant role in transmitting the knowledge to students and evaluated them on the subjects being taught. This fostered a rigid framework of study disciplines, education standards and eventually standardised testing.

Revised Manuscript Received on December 30, 2019.

Rasika Lawrence, Faculty of Business, Victoria University of Undergraduate Programme, Sunway College, Kuala Lumpur Malaysia. (Email: rasikal@sunway.edu.my)

Lim Fung Ching, Faculty of Business, Victoria University of Undergraduate Programme, Sunway College, Kuala Lumpur Malaysia. (Email: limfc@sunway.edu.my)

Haslinda Abdullah, Faculty of Defence Studies and Management, National Defence University of Malaysia, Kuala Lumpur, Malaysia. (Email: drhaslinda@gmail.com)
Over the years, advancement of technologies has been changing significantly especially in education industry. Teaching methods have slowly now transformed into a more technology-based teaching. To keep up with the pace, both teachers and students are aimed highly to improve the digital technologies competences across all levels to enhance the use of technology in teaching and active learning. More changes will be taking place in the future and some have been implied by most of the institutions such as posting results online, uploading and marking assessments online, storing data's online, online platforms widely used to communicate with students for announcements or materials posting purposes and many more.

However, Drucker (1997) said that there will be a lot of changes in ways of teaching and learning in future. The content of the teaching, roles of lecturers and students are something that is needed to be looked at. Technology advancements take place every second thus making it very difficult for educators mainly to keep up with that pace with not having the right or proper technical skills. It becomes tough if not being directed to a right direction. Hence, this requires them to be retrained and may not be very susceptible to the changes being applied. They may even see it as a threat to their job security and shun technology altogether. Haseeb (2018) suggested new educational programmes will have to be developed to meet changing demands in a long run to sustain its competitive advantage since it is constantly a challenge to precisely forecast what lies ahead. Like the industrial revolutions in the past, IR 4.0 will create new jobs, and will also eliminate some of the existing jobs. New educational programmes will have to be developed to meet changing demands. The Malaysian Ministry of Education commented that the role of higher education institutions is only aimed in preparing learners to adapt to the changes introduced by Industry 4.0 and not to fear of losing jobs as there will be new types of job created in future. In a global viewpoint, lack of digital culture, training and knowledge will be the challenges faced while implementing industry 4.0 which is in line with the education 4.0.

\section{What is Education 4.0}

According to Dunwill (2016), education 4.0 is defined as the use of technology in the teaching and learning contexts. This is because, technology enable the human-machine interface to look more universal that contributes to quick revolution in innovation. This is to prepare graduates for future life and work, thus, education 4.0 is much needed. The implementation of education 4.0 is necessary as it is a 


\section{Strengths and Weaknesses of Education 4.0 in the Higher Education Institution}

more practical based approach in the teaching and learning contexts. Education 4.0 offers the view of teaching and learning innovation and uses information and technology in its processes (Gulicheva et al. 2017; Anggraeni 2018). Advancement of technologies has been changing tremendously from time to time especially in teaching and learning. Education 4.0 has been designed as to the response to the needs of IR4.0 where teaching methods have slowly now transformed into a more technology-based teaching. Fisk (2017) explains that the new vision of learning is aimed highly to improve the digital technologies competences across all levels to enhance the use of technology in teaching and active learning.

\section{Education 4.0 in Malaysia}

In today's fast changing technology world, the $4^{\text {th }}$ industrial revolution has set the need to redesign the education system mainly on transforming the learning and teaching strategies around the world. Education 4.0 has been the catchword in every educationist's mind today. As Malaysia grips the emergence of the IR 4.0 on higher education, the Malaysian Ministry of Education plans to revamp the process of teaching and learning students that mainly focuses the theme of Knowledge, Industry and Humanitywith four main principle aspects: redesigning of learning spaces, incorporation of $21^{\text {st }}$ century pedagogies, applying a fluid an organic curriculum, responding to innovations \& new areas of knowledgeand incorporation of the latest learning and teaching technologies as shown in figure 1 below;

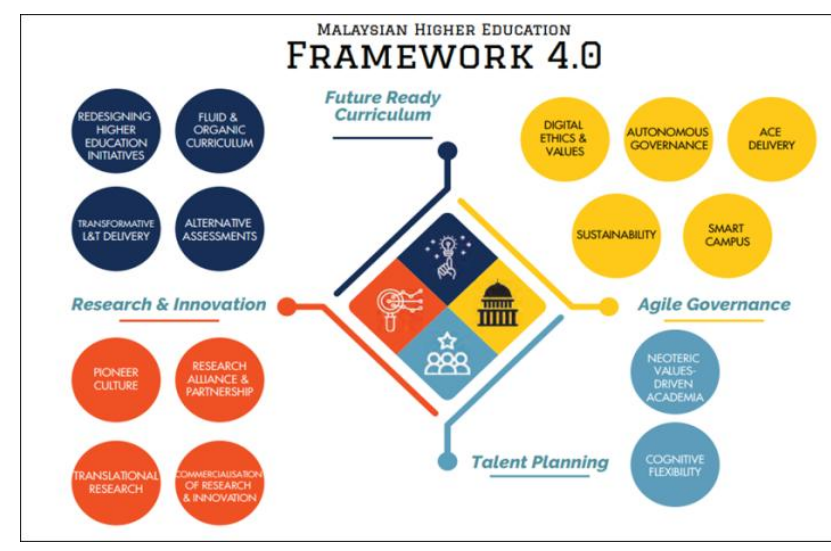

Figure 1: Malaysia Higher Education 4.0 Framework Source: (Ministry of Higher Education, 2018)

In 2016, the Malaysian government introduced a flexible mode of education, namely the Massive Open Online Course (MOOCs). This has been one of the initiatives taken in implementing the online learning in Malaysia, that creates a more globalised online learner globally (Kementerian Pendidikan Malaysia, 2019). The online course is aimed in encouraging online and permanent learning pursuits among Malaysians through diversification of classroom experience and unlimited open access participation via online. Up to date, the government has introduced 63 courses and almost 137,946 learners that belongs to more than 80 countries have been giving their full support towards this online course.

Besides, Accreditation of Prior Experiential Learning $(A P E L)$ is another approach taken by the government of
Malaysia in educating the online learning among the Malaysians. In this context, preference is given to those who lack in qualification but have working experiences to pursue their higher education via APEL. The approach is designed based on an experiential learning that can be gained through experience instead of a normal course (Geomatika University College, 2019).

Another initiative taken by the government is by introducing the $2 u 2 i$ academic program which is completely based on employment training. The main aim of this program is to incorporate academic learning and applications of industrial learning to its learners throughout their learning process. The program basically offers a two (2) years of study and two (2) years of industrial training. This program is designed to have a more practical based learning within the industry, hence students are better prepared in future (Kementerian Pendidikan Malaysia, 2017).

The Malaysian Ministry of Education strongly believes that the initiatives taken in line with the integration of IR4.0 in Malaysia will support the learning institutions to stay relevant and competitive in the emergence of Industry 4.0. In preparing the learners towards a higher level in education in relation to the 4IR, the Ministry of Higher Education is guided by the Malaysia Education Blueprint 2015-2025 (Higher Education) which is established with the determination of achieving Malaysia's education system in bring into line with global trends (Razak 2015).

However, in the near future, the Ministry Education of Malaysia stated that some of the jobs today will no longer be relevant. New jobs will emerge and these will most likely be catering to the digital age. The Minister added that universities have to be prepared to adapt and change their curriculum and delivery so that graduates are able to fill in jobs which are yet to emerge. Technology is moving rapidly and educators have to keep up with this fast pace. Statistics show that the number of unemployed graduates in Malaysia is worrying. There are many possible causes for this. Employers look upon fresh graduates as liabilities who need to be provided with extra training before they can function adequately in their job. Fresh graduates are expected to be highly equipped and competent to face the digital industry. At the same time, educators are expected to make themselves relevance in accordance with IR4.0. Therefore, the objective of this research is to present on the strengths and weaknesses of education 4.0 in Malaysia.

\section{LITERATURE REVIEW}

\section{The Strengths of Education 4.0 From Previous Research}

Opportunity to Experience a More Practical Based Learning.

According to Fisk (2017), education 4.0 benefits students by creating an opportunity to experience a more practical based learning instead of theocratical base knowledge. Learners will need to familiarize and get themselves adopt to the project-based learning. They will need to enhance and

Published By.

Blue Eyes Intelligence Engineering 
improvise their skills and absorb how to apply and mould them. Most of the schools and higher institutions has taken an initiative to make this successful and provide the students a more meaningful learning experience through internships, mentor-mentee programs and collaborative projects (Hussin, 2018). A recent research done by Hariharasudan \& Kot (2018) emphasised that students need to be trained instead of being taught in competing in today's digital driven world in order to be more experienced and skilled for today's industrial operations.

Gain a Deeper Connectivity Compared to Traditional Method

Education 4.0 also connects a learner to gain a deeper connectivity as compared to the traditional ways of learning which is by using the textbook. A research by Diwan (2017) indicates that boredom can easily take place for today's learner as they are constantly looking to fill excitement from visual and auditory inputs. The implementation of education
4.0 provides any learners to experience a visual element that improves the connection between learning concepts and information effectively (Halili 2019).This was very much evident during the 1990s when virtual reality and augmented reality were being in practice into the real-life. The use of augmented reality and virtual reality has increased an interest amongst the students to gain their interest in learning because this technology provides an indirect vision of a real-world setting with better sensory inputs and graphics elements.

Lee \& Shvetsova (2019) stated that most of the researchers see the importance of the augmented and virtual reality applications as tools that assist any a learner to gain a deeper knowledge and understanding on atmospheres, recognize main problems, and test their solutions in specific cases which can be combined with other teaching methods such as project/problem-based learning, flip learning and online education as shown in figure 1 below: -

\begin{tabular}{|c|c|c|c|c|}
\hline $\begin{array}{l}\text { Education } \\
\text { Method }\end{array}$ & VR & AR & Advantages & Disadvantages \\
\hline General class & $+1-$ & $+1-$ & $\begin{array}{l}\text { VR/AR tools save time, express } \\
\text { practical examples. }\end{array}$ & $\begin{array}{l}\text { More common links with general class material } \\
\text { are required; VR/AR material should relate to } \\
\text { the main lecture statements and be supportive. }\end{array}$ \\
\hline Flip-learning & $+/-$ & $+1-$ & $\begin{array}{l}\text { VR/AR can be implemented in both types } \\
\text { of class activity: lecture or practice. }\end{array}$ & $\begin{array}{l}\text { VR/AR can be used only for in-class activity } \\
\text { (not for pre-class or after-class activities). }\end{array}$ \\
\hline $\begin{array}{l}\text { Project-based } \\
\text { learning } \\
\left(\mathrm{PBL}_{1)}\right.\end{array}$ & + & + & $\begin{array}{c}\text { Students may use VR/AR tools to manage } \\
\text { projects; VR/AR helps to conduct } \\
\text { deep research. }\end{array}$ & $\begin{array}{l}\text { VR/AR cannot cover all steps of project } \\
\text { management; workload might be unequally } \\
\text { shared among the members of the team. }\end{array}$ \\
\hline $\begin{array}{l}\text { Problem-based } \\
\text { learning } \\
\left(\mathrm{PBL}_{2}\right)\end{array}$ & + & + & $\begin{array}{l}\text { VR/AR can be implemented for case } \\
\text { studies. Visualization of the problem is } \\
\text { also possible; VR drives core questions } \\
\text { and develops student's collaborative and } \\
\text { investigative skills with regard to } \\
\text { real-world problems. }\end{array}$ & $\begin{array}{l}\text { Students consider the allocation of different } \\
\text { project topics by professors as a disadvantage. } \\
\text { In order to facilitate the transparency of the } \\
\text { process, the professor needs to suggest a } \\
\text { different topic per student or per team. This } \\
\text { means that not every student in class is leaming } \\
\text { the same thing. More resources are needed for } \\
\text { future VR/AR development and specifications. }\end{array}$ \\
\hline $\begin{array}{l}\text { Online } \\
\text { education }\end{array}$ & $+1-$ & $+1-$ & $\begin{array}{l}\text { VR/AR can help professors to manage } \\
\text { tasks or cases easily without traveling; } \\
\text { provides students with responsibility } \\
\text { for self-control. }\end{array}$ & $\begin{array}{l}\text { VR/AR needs more specifications, support } \\
\text { materials, and clear tasks for self-education; } \\
\text { students across the world should use the } \\
\text { same technologies }\end{array}$ \\
\hline
\end{tabular}

Figure 1: Advantages and disadvantages of General Class, Flip-Learning, Project-Based Learning and Online Education

Sources: (Hussin, 2018)

\section{Becoming the 21st Century Instructor}

Education 4.0 is not only beneficial to students but also the teachers in any level of education. Jo \& Lim (2015) stated that practical supports are needed and important in smart classroom to improve the teaching and learning though teachers still engage the chalk and board method in teaching. Anealka \& Hussin (2018) emphasised that every educator is in need to relearn and prepare themselves with the digital tools to meet the demand of the future learner. There are many digital tools which are available online for teachers to access and explore. Technology and Mobile Learning (2016) suggested teachers to equip themselves with these nine fundamental digitals such as record and edit audio clips, create annotated, interactive and engaging video content, use social networking websites, use blogs and wikis to create participatory spaces for students, use social bookmarking websites and share resources in class, create engaging presentations, create digital portfolio's and create non-traditional quizzes. Learning these digital tools clearly shows how digital technology can be combined and integrated in the teaching and learning. Teachers gets a chance to enhance and acquire the skills listed in the top 10

Published By: 


\section{Strengths and Weaknesses of Education 4.0 in the Higher Education Institution}

skills in 2020.

Adding on, students at the same time gains benefit by utilising the technology/devices to gain an education. Students can select the tools and techniques through which they want to acquire this knowledge. Techniques like blended learning, BYOD (Bring Your Own Device) and flipped classrooms by mixing campus-based and distance learning on a module-by-module basis is a good example for this.Students in a long run have greater flexibility in choosing their mode of engagement (Johnson, 2015). Having such technology is fundamental in the teaching and learning concepts of education 4.0 (Hariharasudan \& Kot, 2018).

\section{Shift in Exam \& Assessment Patterns}

In a typical practice, a student's common habit of passing an exam is blindly memorising the key points/information given by the teachers and go for their exams since assessments plays a crucial role in the development of a learner (Borghouts, Slingerland, \& Haerens, 2017). However, this will no longer be a trend to follow as the government recognises that it is essential and necessary to understand that this traditional practice which is focused more on memorising theories may not serve the needs of future talent requirements.

As part of education 4.0, the teaching and learning pattern will not only be merely based on exams, but also focusing the practical and experiential learning-based projects or field work that is suited for future employment. Hariharasudan \& Kot (2018) claimed that education 4.0 literally transforms the traditional ways of taking exams. Learners are examined based in real-time according to their performance when they work on projects in the field instead of being examined based on memorization capacity. According to Marshal (2002), the influence of technology on the education industry should not only be a motive in transforming the learners the way it is imparted, but also the way students perceive education. Teaching and learning methodologies will need to shape the future learners ready so that the educators and learners can move towards a progressive, intellectual, knowledge-driven and future-ready world.

The Weaknesses of Education 4.0 From Previous Research

\section{Lacking in Enthusiasm and Passion}

In a recent research, Colin (2017) stated that he is very much concerned and worried about the educators in implementing the practice of education 4.0. This is due to their enthusiasm and passion in responding to 4th industrial revolution. He also questioned that if the higher institutions are taking much effort to adapt to the initiative taken in developing technologies and human connectivity to the next level. Sidiqqui (2007) also observed that some educators don't primarily see any benefits in having access to the new technologies of teaching and learning. Coming into question, are the educators are ready enough and making themselves relevant in implementing education 4.0 in accordance with IR 4.0? (Rusdin 2018). However, Nagler (2015) stated that teachers need to be a good role model to its learners as when they deliver the lesson with enthusiasm suggesting that it is interesting, important, or worthwhile, learners are possibly to accept the same attitude.

\section{Pressure to Meet the Digital Communities Need}

Due to the competitive business environment, Schleiher (2011) added that the education sectors mainly involving the academicians have to prepare students for jobs that have not yet been created, technologies that have not yet been invented and problems that yet know will arise. Thus, the education sector is worried and pressured to put up with the needs of digital communities. It is essential to comprehend and recognise that educational change is a key for every educator as engagement with different digital technologies and change will be anticipated over the course of a career (Howard \& Mozejko, 2015).

\section{Resistance to Change}

To date, most educators strongly believe that the traditional method of teaching still remains as the best teaching method. According to research done by Abraham \& Reginald (2016), a high level of resistance to change occurs among the educators towards the use of technologies in the classroom. Educators constantly face difficulties to meet the current demands of leaners. Hence, the author commented there is a huge need to change the negative mindsets of these educators towards the use of technologies in the classroom. A research by Higher Education Commission (2016: 50) also said that a culture shift between both students and teachers are necessary to adopt changes.

Siddiqui (2008) also commented that if the technology is to be appropriately used to support student collaboration, inquiry, and interactive learning, an educator's beliefs about teaching/learning must also change. The scholar also commented that some educators have plant in their mind that they are doing a great job and curious what enhancements technology will further bring. Howard \& Mozejko (2015) outlined the three main factors that can influence an educator's decision about integration are culture, confidence and beliefs about technology's usage in teaching. However, a research done by Zhao \& Frank (2003) indicates that if the school does not value the incorporation of technology, teachers are less expected to incorporate it in their practice.

\section{METHODOLOGY}

The basic qualitative research design is used for this study. According to Abdullah (2019), basic qualitative design is conducted to generate an understanding from the data collected and subsequently to be analysed which is usually to be in the form of words. The qualitative design is an approach which is being studied in depth to understand and interpret social phenomena within its natural setting (Creswell 2002; Pope \& Mays 1995; Denzin \& Lincoln, 1994). The use of this design is mainly taken to develop specific and actionable problem statements or research objectives. The research also often beneficial to increase further understanding and crystalize the research problem 
(Zikmund et al, 2013, p.131).

The scope of this research is focused in Malaysia. Lectures in a selected private higher institution is chosen for this study. The total population of lecturers in this selected private higher institution is about 500. However, convenient sampling is used to select lecturers to be interviewed. Upon reaching a saturation point, a total of 6 lecturers have been interviewed. The interview session conducted with each lecturer approximately took up about 30-45 minutes. Audiotape and note taking method is applied during collection o data. The main objective of the interview session is to understand the respondent's perspective, opinions and experiences on the questions being raised. A semi structured interview and unstructured and informal interview is used to obtain clarification on the specific research question to obtain information on respondent's personal experiences and perspectives on education 4.0. Before the commencement of the interview, respondents were briefed on the objective of the interview and they are required to sign the informed consent form to indicate their willingness to contribute towards this research, and to pledge the honesty and sincerity in providing information and responses. Throughout the interview, the respondents are assured of the anonymity and confidentiality of responses

Ensuring the reliability and validity in qualitative research is essential and necessary as it refers to the creditability of the research instrument (Abdullah, 2019). After each interview, a summary of the interview contents is being read and briefed again to the respondents to obtain the respondent's confirmation and validity of information. Lincoln \& Guba (1985) stated that reliability and validity is an essential factor that needed to be carried out in qualitative research to ensure outcome received make sense they are consistent and dependable.

The analytical induction techniques are used to collect data for this study. Analytical induction which is one of the common data analysis techniques used in qualitative research can be defined as "a rigorous process of successively testing each new incident or case against the most recently formulated hypothesis or explanation of the phenomenon under study", (Abdullah, 2019; p.224). Primary and secondary research method is also used to obtained data for this study. For the primary method, the author has collected data mainly from the interview session and meanwhile for the secondary method literature review from previous studies were gathered.

\section{FINDINGS AND DISCUSSIONS\& RESULTS}

\section{Strengths of Education 4.0}

Creates an Opportunity for Educators to Engage in New Technology Tools

Education 4.0 creates an opportunity for educators to engage in new technology tools to make them relevant in the industry. Educators are needed here to play a crucial role in connecting the students and real work life. This requires designing tasks or activities that engages learners to become involved in the thinking and learning proccess. For instance, using the flipped classroom technique will enable learners to complete a certain task beyond the classrooms via technology and in the meantime assists teachers to provide a more engaging learning experiences that promotes a more independent learning environment.

Indeed, education 4.0 provides an opportunity for educators to engage in new teaching methods which is similar and consistent from a research conducted by Fisk (2017). From the lecturer's perspective, with the advancement of technology, the teaching process can be expanded and develop a student's learning through collaborative learning as mentioned by Hussin (2018) earlier. The technology has always been a supportive part in the teaching and learning environment. However, Johnson et al., (2016) argues that choosing the best technological tools can be the utmost challenge for an educator. Education 4.0 have created an opportunity and a huge platform for all educators to engage in new teaching styles. Teachers all around the globe uses, create, manipulate and share information on computer devices and over computer networks for many years. In a recent forum, the Education Minister Dr Mazlee Malik (2018) has emphasize his thoughts that an educator should be dynamic and able to become accustomed to various changes to diversifies the teaching and learning methods. Keeping in mind, developing students' knowledge and skills related to technology in the education provides an important grounding for later in life, therefore every educator needs to have a proper knowledge on the application of the tools to educate the learners.

A research by Garba, Byabazaire \& Busthami (2015) commented that technology has made most of the teacher's life easier whereby many effective and innovative tools such as the power point presentation, smartboard technologies and some software applications such as the SPPS software and Panopto are used to smoothen the transition in teaching. Education 4.0 has enabled educators to deliver education much easier to its learners by implementing the innovation technology tools. It is no doubt that the teachers are gaining various knowledge on the educational technology tools. This finding is consistent and similar and has been confirmed by source of information from the Mobile Learning (2016) that indicated that how digital technology can be integrated in the teaching and learning process.

\section{Enhances the Knowledge \& Usage of Technology}

Another strength of education 4.0 is that it enhances the knowledge and the usage of technology to both educators and learners more in depth. Since the governments have priorities getting digital technology into schools, colleges and universities with large-scale, it is crucial for every educator to learn and know how to operate and integrate the technology tools effectively. As we are aware, almost all institutions have been welcoming the multimedia approach widely by using audio-visuals tools, MS PowerPoint \& other devices for better understanding of concepts. This has also proven and emphasize the educator's role is not only limited to reading books but also the internet technology. For this reason, educators should be aware and informed on the tools 


\section{Strengths and Weaknesses of Education 4.0 in the Higher Education Institution}

to not only develop student's understanding, but also to stimulate their interest to improve subject proficiency. Students will also be at a par with the latest technological usage and will be more knowledgeable in utilizing the technologies at their fingertips.

Nevertheless, education 4.0 enhances knowledge and the usage of the technology for both educators and students. In today's teaching and learning process, technology is necessary and important (Eady, 2013). Finger \& Trinidad (2002) stated that learning and teaching with technology is beneficial for both educators and students to gain various knowledge and information about their respective subject areas. The author further added that the technology-based teaching and learning stimulates many interesting ways such as brainstorming, educational videos, mind-mapping, guided discovery and others that creates a more meaningful experiences in learning and teaching contexts. The findings found in this study is in line with a study conducted by Halili (2019). The author stated that learners get to explore more knowledge and information rather than just depending on the textbook content. The author further explained this is evident when the virtual reality and augmented reality were being in practice into the real-life that has increased the interest amongst the students as the technological advancements provides a vision of the real-world setting. Adding on, students are exposed to a more hands-on activities in a technology-based course that will cultivate their understanding and knowledge about the subject, whereas the teachers gets a chance to design their lesson plans in a more effective and interesting manner that gives a huge positive impact on a student's active learning (Finger \& Trinidad, 2002; Jorge et al., 2003; Young, 2003; Jamieson-Procter et al., 2013).

However, Türel and Johnson's study (2012) argues that regardless of having a significant resource allocated to integrate technology in the classroom, many teachers have struggled with disruptions that devices can bring such as low connectivity, virus spell and printer not operative enough that had their work negatively impacted. Ghavifekr \& Rosdy (2015) concluded that those technical glitches often a major reason and a source of frustration that causes interruptions in the teaching and learning process for both teachers and studets.

\section{Development of Technology Classroom Into The $21^{\text {st }}$ Century Skills}

Adding on, education 4.0 creates a platform for every educator to promote the development of technology classroom into the $21^{\text {st }}$ century skills. Advancement of technologies has been changing tremendously from time to time especially in teaching and learning. As we are aware, the 21 st century is characterised with amazing development and progress in information technology and it makes more senses to integrate more educational technologies into the classroom. All educators are now needed to be more responsible in better preparing today's graduates for a $21^{\text {st }}$ century world that requires exposing them to technology. Looking at today's life and working environments, it requires far more than thinking skills and knowledge. Educators needs to master the competencies even before delivering them to the students to ensure positive learning outcomes are achieved. Education 4.0 gives each and every educator the hope to reshape the lives and career of their students. By integrating technology into the classroom, educators stand a chance to change the way they used to teach and provide students with the tools that will take them into the $21^{\text {st }}$ century.

This study is line with astudy conducted by Jo \& Lim (2015) that emphasised that practical supports are needed and important in developing the technology-based classroom into the $21^{\text {st }}$ century skills. Male (2016) commented that incorporating technology into classroom will offer a greater opportunity to change the way teachers engage with their students that will result in better networking, collaborative learning and problem solving which is in line with the study conducted by Anealka \& Hussin (2018).

Every educator needs to be more responsible in better preparing today's graduates for a $21^{\text {st }}$ century world that requires exposing them to technology and digital skills which is consistent by a research conducted by Technology and Mobile Learning (2016). Rusdin (2018) stated the 4C's skill namely communication, critical thinking, collaboration and creativity is crucial in developing the $21^{\text {st }}$ century learning. Azmi \& Nurzatulshima (2017) added that developing the $4 \mathrm{Cs}$ in $21^{\text {st }}$ century learning skills is essential and every educator should be playing the main role in carrying out the responsibilities well. In making this initiative align with the $21^{\text {st }}$ century learning, the Ministry of Education stated that every educator should own six (6) skills in being the $21^{\text {st }}$ century educator namely, mastering knowledge/subject/content, mastering $21^{\text {st }}$ century pedagogy, mastering the skill on tracing people's development and achievement and provide support, mastering learning phycology skill, possess counselling skill and competent in using information technology and media (Malaysian Education Transformation Bulletin, 2015).

However, a report by President's Committee of Advisors on Science and Technology (1997) reported that all investments in technology will be no use if the educators are not ready to integrate technology into classroom instruction. Yunos (2015) also added that teachers go through a tremendous challenge due to the many new skills introduced with a limited time given to incorporate in their teaching. The author further added that the efforts to introduce the $21^{\text {st }}$ century skills amongst the learner is difficult as some learners varies in having a different previous knowledge, passion, motivation and learning style.

\section{Weakness of Education 4.0}

\section{Resistance to Change}

One weakness of education 4.0 is resistance to change factor occurs at a greater level. The teachers will resist to change or will not step out from their comfort zone that they have been putting into practice for many years. Many educators feel unprepared to use technology to support student learning. Most of them are comfortable teaching the traditional ways. For instance, teacher refers to text book as

Published By:

Blue Eyes Intelligence Engineering 
much as they want to seek understanding on certain theories or definitions. As much as we can't deny that the traditional method has contributed greatly to the current levels in education industry, in meantime, educators plays a crucial role in shaping the lives of their students in today's fastgrowing technology world. In order to achieve the desired outcome, the educators need to shift their mind-set and give themselves a pace to adopt the new things that comes along their ways. Keeping in mind, the demand from the new generation are constantly changing, therefore educators have to keep up with the standards of the lifelong learning.

Technology has played a strong role in educating the young learners in today's fast-growing technology era. However, one of the challenges faced in the education industry is that most educators are seeing technology as a tool that has a demand in the teaching and learning process. The study is in line with the previous study conducted by Siddiqui (2007) whom concluded that most teachers does not see the importance or necessities in having access to the latest technologies especially in teaching and learning. Some teachers feel they have been doing a great job in the classroom and still doubt what can the technology further do, and some teachers are also the ones that has the knowledge on the technology but refuses to use them in classes due to not having plans to use them in their respective classes. Some of them are not convinced of the potential benefits/value of the new technologies regarding supporting teaching/learning process that in a way show resistance at a greater level.

Teachers are always expected to stay relevant to current teaching technologies (Burroughs, 2017). Azmi \& Nurzatulshima (2017) \& Rajendran (2001) stated there are teachers who still applies the traditional teaching method till now which is consistent with the findings. The traditional thus the learning process also become limited to a learner. Yunos (2015) reported that when a limited strategy applied in the teaching and learning contexts, learners seemed to show less interest in learning process. in line with that, Mahamod (2011) concluded that this may be a reason of failure in implanting the $21^{\text {st }}$ century skills in both educators and learners. On the other hand, some teachers feel they are not the experts in dealing with technology and needed more adequate time to learn since it takes up an amount of time to learn new tools and software (Abraham \& Reginald, 2016). Bennett, Maton \& Kervin (2008) stated that although we have born into a technologically rich world, some of us may still not be users of technology that may be a reason to resist. However, offering access to technology is never acceptable. Meaningful development of technology-based knowledge is important for all learners in order to maximize their learning (OECD, 2010).

Hence, to keep up with the current demands of learners, a need to change in mindsets is essential towards adopting the new usage of technologies in the classroom. Every educator needs to obtain and utilise the necessary information and communication technologies of today. It is proven that, an educator with the positive mind-set are most likely the ones that produces a conducive learning environment. Abraham $\&$ Reginald (2016) further added that if the technology is to be appropriately used to support student collaboration, teaching approach has limited the involvement of a learner

inquiry, and interactive learning, teachers' beliefs about teaching and learning must also change

\section{Digitally Connected, Socially Disconnected}

Our society is rapidly evolving in technology with no doubts. Literally every information is available at our convenient at anytime anywhere. With the amazing advancements of technology, we all get connected all across the globe in a second. In reality, technology is in many situations essentially removing us more and more from each other. Educators are so busy delivering the education to their students using the online educational tools that is accessible 24/7. This has limited the face to face communication between the teachers and students whereby the students hardly share their problems openly to their teachers. In a way, technology advancements have limited the engagement or involvement of an educator towards its learner.

As educators we strive for students to engage with our subject beyond a superficial level. We want them to be active learners, learners who have a thirst for discovery and knowledge. Current digital technologies cannot enable this type of social and collaborative learning as well as a teacher can, since such learning environments are highly dependent on the inter-personal relationship between the teacher and their class. Adding on, some of the assessment designed has some technology involvement but still do not use technology to its full potential to measure a broader range of desired educational outcomes, especially non-cognitive competencies that involves social and emotional learning that requires the educator's involvement purely.

The study found that technology makes learners get disconnected from real world. This study is in line with a research conducted by Kushlef, Proulx \& Dunn (2017) which stated that individual nowadays are depend too much on technology instead on other people for any sorts of information and McCrindle and Wolfinger (2010) found that they also take technology for granted at the same time Sutton (2013) claimed that technologies further disconnect people from practical world and push an individual towards a cybernetic world. This further affect the interpersonal relationship amongst the people around them as it is never the same as before. However, the author commented it is not to say technology is irrelevant in a socially collaborative learning environment but technology can be most effective when used frequently enough to raise the level of understanding from both teacher and student perspectives.

\section{CONCLUSION}

Technology in education has its own strength and weaknesses, but proper implementation might help keep the drawbacks to a minimum. Better planning is necessary. In line with the industry revolution 4.0, Malaysia needs to enhance and develop the education system in order to be one of the competitive countries in the world. Education 4.0 helps a learner to further understand the learning contexts effectively compared practicing those traditional approach Therefore, every educator needs to change a step forward in 


\section{Strengths and Weaknesses of Education 4.0 in the Higher Education Institution}

making this positive since the students are more favour towards using technology.

This study contributes to the literature by filling up the gaps in literature and expanding the body of knowledge regarding education 4.0 and the use of technologies in teaching and learning. To the policy makers (policy review and developments), this study should able to provide insights regarding the strengths and weaknesses of education 4.0 to the Ministry of Higher Education in order to review policy and strategic direction on the use of technology-based teaching and learning. To practise able to assist private higher education universities in the use of technology-based teaching and learning more effectively and efficiently. Technology is necessary for now and future. Educators to be more involved in the use of technology based in teaching and learning

This study only covers the strengths and weaknesses of education 4.0 in Malaysia higher private institution. This might limit the understanding on readers if different industries are being looked at. Besides, this research is emphasizing more on the viewpoints of the educators from the private higher institution. For the population and sampling method, questions to be distributed should include a higher number of respondents that the author may want to look at the respondent's category that includes the students, lecturers and top managements who are preparing the strategies for education 4.0. Besides the research mainly focuses on using the qualitative method with a selected population and small sample size that consist of only 6 lecturers in a selected private higher institution in Malaysia. The research is highly recommended to use quantitative survey in future which is to be distributed to lectures and students for more detailed outcome. The research should also explore and obtain data's using all the other private institutions. It is highly recommended for further research about moving out the study based on a specific sector under service industry or another region of Malaysia. This is mainly because this research is merely emphasized on strengths and weaknesses of education 4.0 in Malaysia. Besides, this research can be better and improved by studying the education 4.0 in different level of institutions.

\section{REFERENCES}

1. Abdullah, H (2019). Research Methods and Report Writing. Kuala Lumpur, Malaysia: UPNM Press

2. Abraham, O., \& Reginald, A. (2016). E-Education: Changing the Mindsets Of Resistant And

3. Saboteur Teachers. Journal of Education And Practice. Vol.7, No.16, ISSN 2222-1735.

4. Ahmadi, MR. (2018). The Use Of Technology in English language learning: A Literature Review. International Journal of Research in English Education (2018) 3:2

5. Boyles, B. (2017). Virtual Reality And Augmented Reality In Education. Centre For Teaching Excellence, United States Military Academy, West Point, NY.

6. Burroughs, A. (2017). Q\&A: Education Technology Expert On Teaching the Next Generation of Teachers. Milwaukee Avenue, Vernon Hills, IL 60061 . https://edtechmagazine.com/higher/article/2017/02/qa-educationtechnology-expert-teaching-next-generation-teachers

7. Diwan, P. (2017). Is Education 4.0 An Imperative for Success Of 4th Industrial Revolution?

8. Eady, MJ., \& Lockyer, L. (2013). Tools For Learning: Technology And Teaching Strategies. Learning to Teach in the Primary School, Queensland University of Technology, Australia. pp. 71 http://ro.uow.edu.au/cgi/viewcontent.cgi?article=1413\&context=asdp apers

9. Elmahdi, I., Al-Hattami, A., \& Fawzi, H. (2018). Using Technology for formative assessment to improve students' learning. The Turkish Online Journal of Educational Technology. Volume 17 issue 2.

10. Garba, SA., Byabazaire, Y., \& Busthami, AH. (2015). Toward The Use Of 21st Century Teaching Learning Approaches: The Trend Of Development In Malaysian Schools Within The Context Of Asia Pacific. Ijet. Volume 10, Issue 4.

11. Geomatika University College (2019). Admission By APEL.

12. Ghavifekr, S. \& Rosdy, WAW. (2015). Teaching And Learning With Technology: Effectiveness Of ICT Integration In Schools. International Journal Of Research In Education And Science (IJRES), $1(2), 175-191$

13. Gonsiewski, MA. (2014). Resistance To Change: Teacher Variables That May Influence Acceptance Of Curriculum based Measurement. Unpublished Masters Thesis From Appalachian State University and Department of Psychology.

14. Halili, ST (2019). Technological Advancements in Education 4.0. The Online Journal of Distance Education And E-Learning. Volume 7, Issue 1

15. Hariharasudan, A., \& Kot, S. (2018). A Scoping Review on Digital English And Education 4.0 For Industry 4.0. Social Science. Vol, 7 227.

16. Howard, AK., \& Mozejko, A. (2015). Teachers: Technology, Change and Resistance.

17. Hussin., AA (2018). Education 4.0 Made Simple: Ideas for Teaching International Journal of Education \& Literacy Studies.

18. In M. Henderson \& G. Romeo (Eds.), Teaching and Digital Technologies: Big Issues And Critical Questions (Pp. 307-317). Port Melbourne, Australia: Cambridge University Press

19. Johnson, AM., Jacovina, ME., Rusell, DG., \& Soto, CM. (2016). Challenges and solutions when using technologies in the classroom. Adaptive Educational Technologies for Literacy Instruction.

20. Kushlev., K. Dunn., E. and Proulx., J.D.E. (2017). Digitally Connected, Socially Disconnected: The Effects of Relying on Technology Rather Than Other People

21. Lee, JH., \& Shvetsova, OA. (2019). The Impact Of VR Application On Student's Competency Development: A Comparative Study Of Regular And VR Engineering Classes With Similar Competency Scopes. Sustainability. Volume, 11, 2221.

22. Male, T. (2016). Digital technologies: Implications For Educational Organisations And Settings In The Twenty-First Century. Educationa Futures. Vol.7(3).

23. Maria, M., Shahbodin, F., \& P, NC. (2018). Malaysian Higher Education System Towards Industry 4.0 - Current Trends Overview. International Conference on Applied Science and Technology. Issue 1 $10.1063 / 1.5055483$

24. Marshal, JM. (2002). Learning with Technology. Evidence That Technology Can And Does Support Learning.

25. Ministry of Higher Education. (2018). Framing Malaysian Higher Education 4.0: Future Proof Talents.

Department of Higher Education Malaysia https://umcms.um.edu.my/sites/adec/pdf/Framing_malaysian_HE4.0. pdf

26. Ministry of Education Malaysia. (2019). Massive Open Online Courses (MOOCS).

27. Ministry of Education Malaysia (2017) https://www.moe.gov.my/en/muat-turun/penerbitan-dan-jurnal/2u2i

28. Nagler, KS. (2016). Effective Classroom-Management \& Positive Teaching. English Language Teaching; Vol. 9, No. 1. ISSN 19164742

29. Rind, IA., Mari, MA., \& Shahreza, MAH. (2019). Analysing The Impact Of External Examination On Teaching And Learning Of English At The Secondary Level Education. Journal Cogent Education. Volume, 6, Issue 1.

30. Rusdin, NM. (2018). Teachers' Readiness in Implementing 21st Century Learning. International Journal of Academic Research in Business and Social Sciences, 8(4), 1293-1306.

31. Sandholtz, JH., \& Reilly, B. (2004). Teachers, Not Technicians: Rethinking Technical Expectations for Teachers. Volume 106 Number 3, March 2004, pp. 487-512

32. Sani, R. (2018). Embracing Industry 4.0

33. Shahroom, AA., \& Hussin, N. (2018). Industrial Revolution 4.0 And Education. International Journal Of Academic Research In Business And Social Sciences, 8(9), 314319 .

34. Themes, A. (2019). Future Ready Education: The Landscape of Education 4.0. 
35. Wikramanayake, G. (2005). Impact of Digital Technology on Education. Unpublished Thesis From University of Colombo School of Computing. 